\title{
Factors that Affect Commercial Banks Customers Intention towards Electronic Payment Services in Jordan
}

\author{
Malek Mohammad AL-Majali ${ }^{1} \&$ Amin Ayed Bashabsheh ${ }^{1}$ \\ ${ }^{1}$ Marketing Department, Faculty of Business, Mu'tah University, Jordon \\ Correspondence: Amin Ayed Bashabsheh, Marketing Department, Faculty of Business, Mu'tah University, \\ Jordon. E-mail: dralmajalimalek@yahoo.com
}

Received: December 27, 2015

Accepted: January 19, $2016 \quad$ Online Published: February 25, 2016

doi: 10.5539/ibr.v9n3p79

URL: http://dx.doi.org/10.5539/ibr.v9n3p79

\begin{abstract}
This study aims to identify the factors influencing commercial banks customers intention toward electronic payment services in Jordan (AL-Karak) province. To achieve the aim of the study, a questionnaire has been developed to explore the effect of the independent variables (relative advantages, simplicity, security, consciousness and self efficacy) on the dependent variable (banks customers intention toward E-payment services). Six hundred questioners had distributed and 543 were returned to be valid for the final analysis with response rate of $90.5 \%$. SPSS v 18 was used to test the reliability and composite reliability, normal distribution and correlation between the study variables. Also, Amos v 8 software has been used to examine the study hypotheses. Results of this study indicates an acceptance to four hypotheses related to influence of security, self efficacy, consciousness and simplicity continually. We reject one hypotheses related to relative advantages on banks customers toward E-payment services adoption. Finally, set of recommendations had been present throughout the study.
\end{abstract}

Keywords: e-payment services, customers intention, security, self efficacy, consciousness, simplicity

\section{Introduction}

The internet changed the world today. These quick and recurrent changes contributed in making individuals more acceptable and in line with different and various technological applications around us. At the same time, dealers with this technology became unable to accept the idea of living without daily and effective use of available technological means like PCs and telephones. Most of these devices are connected with the internet services that join people with each other despite far away distances. These changes contributed in transforming communicative patterns as they depend greatly on the internet web and social networks that contributed in building social relationships and facilitating communication process. These days, in the existence of society, school, work environment and commercial organizations, we are obliged to use all communicative technological means to get information, products, building relationships and performing life activities. For the aforementioned reasons, the Jordanian government entered internet technology and its applications to Jordan in the middle of 1990s (Ministry of Information and Communication Technology, MOICT, 2015). This environment witnessed many quick developments and changes in response of the government's vision of the importance of this technology. Since that time, many public and private companies exploited this technology to provide the latest services for its customers to keep pace with the tremendous developments the world witnessed lately in profit and non-profit sectors. In 2001, the government entered the DSL service with a small number of about (128.000) users, to amount 5.700.000 user (Internet world stats, 2015).

As a result of these procedures, there are a variety of serious steps taken by the Jordanian government in the information and communications sector to develop it to provide the best services for Jordanian people (Jordan.gov, 2015). The most prominent step was the initiation of electronic government project in response to His Majesty King Abdulla II's vision in 2002 by developing a national strategy that aims at improving the quality of services provided for citizens and business sector, raising the productivity and efficiency of public sector, supporting and facilitating all transactions and public services to be more efficient and competitive at the same time, reducing costs and ease of communication with the governmental organizations, providing required information safely and accurately at the right time. The government put a legal legislative in collaboration with the concerned authorities and ministries like Ministry of Information and Communication, Ministry of Justice, 
Ministry of Finance, and Central Bank of Jordan In order to develop laws and legislations that control reciprocal process to get different governmental services and trying to restrict any violation or possible problems (Jordan.gov, 2015).

The government began applying the E-government in accordance with these inclinations; the Jordanian government encouraged the applications and activities of the E-government by developing legislations and laws and providing all necessary facilitations for the concerned and interested authorities (Shannak \& Aldhmour, 2009). The most recent service is E-bills (E-Fawateercom) which was launched as one of the e-commerce applications under the umbrella of the services offered by the e-government of Jordan which were applied through the Central Bank in 2012. The electronic payment services (e-bills, E-Fawateercom) through the electronic payment gate which was established in collaboration with (Your Payments Company) for electronic payment as the main operator of the gate, "MIGS" for electronic payment as a subsidiary of Master Card and "Emerging Markets Payments Jordan" (EMP) as the host company. A capable electronic system was established to accomplish payment processes by citizens for governmental agencies and joint private sectors by using the internet to facilitate safe electronic payment operations. This system might be used by financial organizations and providers of the offered services. This system works under the umbrella of rules and laws that ensure the secrecy of security and protection of buying procedures and access of services by citizens' subscription in this service. Since the application of this type of services in Jordan, there were few studies that were interested in identifying the factors that affect the attitudes of customers in Jordan by using the electronic payment services in Jordan (CBJ, 2015).

\section{Problem of the Study}

As we mentioned earlier, the Jordanian government made many procedures and facilitations in early stages of adopting internet technology, developing the public sector by establishing the Ministry of Information and Communications and trying to upgrade by developing future strategies concerned with using electronic programs and means like the e-government that mainly aims at upgrading qualitative services. These services contribute in the ways of communications between citizens and the government and the ability to get varied service quickly, effectively and easily. At the same time, many organizations in the private sector make use of the tremendous developments due to technological revolution by adopting electronic applications in the field of e-commerce, online shopping and electronic services in general.

Despite all these procedures taken by both of the public and private sectors, Jordan like other developing countries encounters several challenges in all walks of life and especially in the field of information and communication technology. There is a wide spread in the Jordanian market for the cell phone users whereas there is a weak spread of means of access to the internet network (Shannak, 2013), as well as the customers' acceptance for the electronic services provided by the government in its initial stages because of lack of experience and knowledge for the application of these services, in addition to the weak application of regulations and laws and monitoring the internet network by the government (Al-Naji \& Hamdan, 2009). The Jordanian government faces several challenges due to adopting electronic services by citizens. A good number of citizens don't have PCs that enable them from accessing the system or using these services effectively. These citizens need guarantees concerning safety on the internet because some users were subject to theft (Heba \& Tamara, 2009).There are some difficulties that face applying the e-government by customers represented by lack of awareness and the necessary basic skills to use the internet network by the public. Increasing prices of accessing internet services plays a main role in preventing citizens from using services provided by the government, as well as, the negative feeling among citizens toward the government's ability to provide protection for them against those who steal their accounts and manipulating them (Elsheikh, Cullen \& Hobbs, 2008). There are several economic, social, environmental and political dimensions that may have negative effects on the citizens using the governmental electronic services on different levels (Vishanth, Al-Busaidy, \& Moaman, 2010).

The most important factors that represent big barriers in front of the application of the e-government and its activities in Jordan are: Weakness of the budgets of the government to apply the programs of the e-government and their expensive costs,social factors and human experiences of people, the complicated technological issues, resistance of the public sectors' employees, trust and privacy factors, the legal frames that organize the work of these governmental programs and the administrative (Al-Shboul, Rababah, Ghnemat, \& Al-saqqa, 2014). The attitudes of Jordanians and levels of awareness of the governmental electronic services contribute in enhancing and accepting by customers for this kind of services (Al-Jaghoub, Al-Yaseen, \& Al-Hourani, 2010). This study will try to answer the following main question: What are the major factors that influence the attitudes of the customers of banks in adopting electronic payment services as one of the e-government services in Karak? 


\section{Objectives of the Study}

This study aims at establishing a capable theoretical model to identify the level of using e-payment services among customers of banks in Karak, to investigate factors influencing on bank customers positively or negatively in adopting e-payment services. In addition, the study aims at analyzing special data in this study to come out with results and recommendations that might be beneficial and important for decision makers, managers to know the factors that affect their attitudes toward using e-payment services in general. It also aims at referring to previous studies and literature, making sure of some factors to support the scientific library with a scientific contribution. Most studies in Jordan discussed generally subjects concerning the e-government, e-commerce and e-buying. A very small number discussed the subject of e-payment services in particular.

\section{Literature Review}

Jordan is a small country that occupies a strategic situation between Iraq, Syria, Palestine, Egypt and Saudi Arabia with 6.675 .000 inhabitants and limited natural resources. Jordanian government works hard to provide ways of entertainment for its people through regional cooperation. The country depends on foreign resources to fulfill most of its needs especially energy. Jordan is classified by the International Monetary bank as "middle-income countries". The GDP per capita is $\$ 5749$. In the field of technology and communications, Jordan is considered a pioneer in modernity. Information technology and communications' sector is the most modern one in Jordanian economy with the highest percentage with 50\% per annum (Dos, 2015). The ratio of using computers for those who are 5 years old is $50.2 \%$ of the total number of the population. Jordan entered technology early to its markets trying to support the public and private sectors with the most modern technological techniques and means and electronic services.

\subsection{The Internet in Jordan}

In the mid 1990s, the Jordanian government entered the internet in the Jordanian market with limited number of users at that time till launching the (DSL) in 2001 with 4000 users. After that, the internet market witnessed great changes during (2006-2013) on the level of the market, companies and technology of electronic services and on the level of the users' turnout to changing their needs they want to fulfill by using this technology. The market witnessed the entry of new wireless technologies that contributed greatly in broadening the base of usage as (Y Max) technology and the 3rd. generation service. The latter was the biggest contributor in increasing the number of users while providing internet services through cell phones (MOICT, 2015).

The number of internet users from Jordanians especially home subscriptions whereas the subscriptions increased from 206.000 at the end of 2006 to 105 million subscriptions at the end of 2013, most of them from the 3rd. generation. Generally, in 2014, the number of internet users in Jordan arrived 5.700.000 users (internet world statis., 2015). The statistics showed a wide spread for smart phones which became a main way for using internet in addition to PCs, laptops and tablets. The percentage of using these phones more than $60 \%$ of the number of people using cell phones in general (MOICT, 2015). These days ,the internet services developed in the local market in several techniques wired and wireless through many providers. This provides a competitive atmosphere that encouraged the increase in demand for the service and its wide spread between Jordanians who considered the service as one of the basic requirements of daily life for social communication or running work.

\subsection{Information Technology and Communication in Jordan}

Since the establishment of the Ministry of Communication in 2002, the sector of information technology and communication. In the last five years witnessed a remarkable improvement because the government made serious steps to develop and modernize all means related to communication processes between special authorities. These developments contributed in finding many opportunities to create competitive fields in the public and private sectors through the governmental strategy for the period (2007-2011). This strategy aimed at achieving two main objectives. Firstly, to establish the information technology and communication sector which is capable of providing an investing environment full of opportunities that contribute in growth in all fields. Secondly, to define the role of the Jordanian government in contributing in developing and modernizing the basic programs that work to create facilitations for the Jordanian communicative environment (MOICT, 2015). According to applying this strategy. The Jordanian government carried out procedures that encouraged the transactions of e-commerce through cooperative work with some governmental authorities represented by Ministry of Public Works, Ministry of Justice, Ministry of Finance and the Central bank. The aim is developing the infrastructure and establishing a legal legislative frame that ensures the protection of e-commerce procedures in different fields (MOICT, 2015).

With the development of Information Technology and Communication round the world, the percentage of 
prevalence and use of mobile phones reached $147 \%$ around the world and $75 \%$ percentages for using the internet in 2014. The findings for some statistics indicated that Jordan was considered one of the pioneer countries in the field of using cellular phones with $60 \%$ percentage of the size of the total population. The size of returns from Information Technology sector increased from 2.000.000.000 in (2000) to 637.940.326 in 2013 whereas the volume of the foreign investments increased in this sector from 1.384.181 in 2001 to 4.175 .000 in 2013 (MOICT, 2015). The Information Technology and Communication in Jordan is the most important economic sector for the budget of the Jordanian government, reducing unemployment level, and finding unlimited investment opportunities. This allowed the public and private sectors to have competitive advantages that contributed in developing technological means to enhance the services provided from these beneficiaries and end customers.

\subsection{The E-Government in Jordan}

The initiative of establishing the national e-government came as a result of King Abdulla II's vision that called for the necessity of putting a realistic strategy and a work plan to develop information technology sector. The e-government program was applied in September 2001 through the Ministry of Communications and Information technology to increase the levels of knowledge among the Jordanian society by improving the economical, technological, social and cultural fields (Jordan, gov., 2015). The program aimed at moving from traditional governmental procedures to the electronic practices that aim at improving the governmental performance in providing services .efficiency of performance, accuracy and reducing time, effort and costs to achieve governmental transactions and reaching to a high degree of satisfaction of those who receive service. In addition to integration, coordination and concentrated efforts between authorities aim at efficiency and effectiveness of the governmental performance. The Royal vision wanted the Information Technology sector to be the major partner of economical and social life by providing the e-services for every Jordanian citizen (Jordan.gov, 2015).

Jordan is considered one of the pioneer developing countries in the field of applying e-government services in the Middle East. The Jordanian government was able to establish and develop the infrastructure to provide e-services for citizens, contribute in providing and supporting providers of internet services, establishing special electronic websites for each service governmental project to make it easy for citizens to reach favorable services at the least time, effort and cost. The most important interests of the government are the applications and activities of e-commerce by providing all means necessary for practicing these commercial transactions by many service providers. Despite of the increasing numbers of internet users, the e-commerce usage is still in the developing stages. So the government applied e-government programs to encourage working on the applications of e-commerce by ensuring processes, giving facilities, reducing taxes, making promotional campaigns to increase citizen's awareness in the importance at using e-commerce activities. The study of (Al-Jaghoub, Al-Yaseen, \& Al-Hourani, 2010) showed that e-government services are varied and can be used by citizens of Jordan for different fields. The results from the sample of the study showed that the e-government services were used at its highest level for service to inquire about the traffic violations.

Table 1. E-governments users percentage in Jordan

\begin{tabular}{ll}
\hline \% of users & E-government service \\
\hline 81.3 & Inquiring about traffic violation \\
51.1 & Inquiring about weather condition \\
39.4 & Renewing passports \\
28.4 & Renewing ID \\
18.9 & Renewing Driving license \\
17.2 & Paying bills \\
16.8 & Inquiring about car taxes \\
10.1 & Job applications \\
8.1 & Renewing Health Insurance Card \\
7.9 & Paying taxes \\
7.3 & Recovery of taxes \\
7.1 & Inquiring about Income taxes \\
6.5 & Inquiring about taxes \\
1.6 & Renewing Family documents \\
\hline
\end{tabular}

Source: The study of: (Al-Jaghoub, Al-Yaseen, \& Al-Hourani, 2010). 


\subsection{E-Payment Services in Jordan (E-Fawateercom)}

The e-payment process is defined as "the process of transforming any kind of values from the payer to the payee electronically (Al-Ma'aitah, 2013). But the e-payment system is defined as "the existence of an e-payment gate in an integrated form and supportive banking services to facilitate payment in current transactions through the internet and payment by the cell phones (CBJ, 2015). In response to the tremendous developments that the Jordanian market witnessed in the field of communications an Information technology, the e-payment services were applied in Jordan, the orientations of the Jordanian government toward the necessity for adopting e-services that can facilitate access for services to improve level of economical and social life. This will be reflected on the economical system in general through cash flow processes, promotional campaigns for e-commerce applications, reducing costs as a result of saving the bills' printed paper (Jordan.gov, 2015). So the government developed an e-payment system called "e-fawateercom" as an electronic website, specialized for inquiries about monetary transactions electronically without need to field visits by the service providers in different ministries that aim at providing time and achieving tasks safely and without any efforts and additional costs.

E-fawateercom is the first national and governmental service to be applied by the Central Bank in Jordan in conjunction with public and private providers of services and Jordanian Bank in June, 2014 which enable citizens, users or foreigners who has bank accounts in Jordan from inquiring, reviewing their bills electronically through ATM machines, Internet banks, phones, banking branches or any available payment way. These payments can be directed to pay water electricity bills, communication, education, health, taxes, governmental fines or any service is designed to be able to communicate between several parties like banks owning customers' accounts and companies providing the service through the internet network, the Central Bank that monitors movements of this service in all direction (CBJ, 2015).

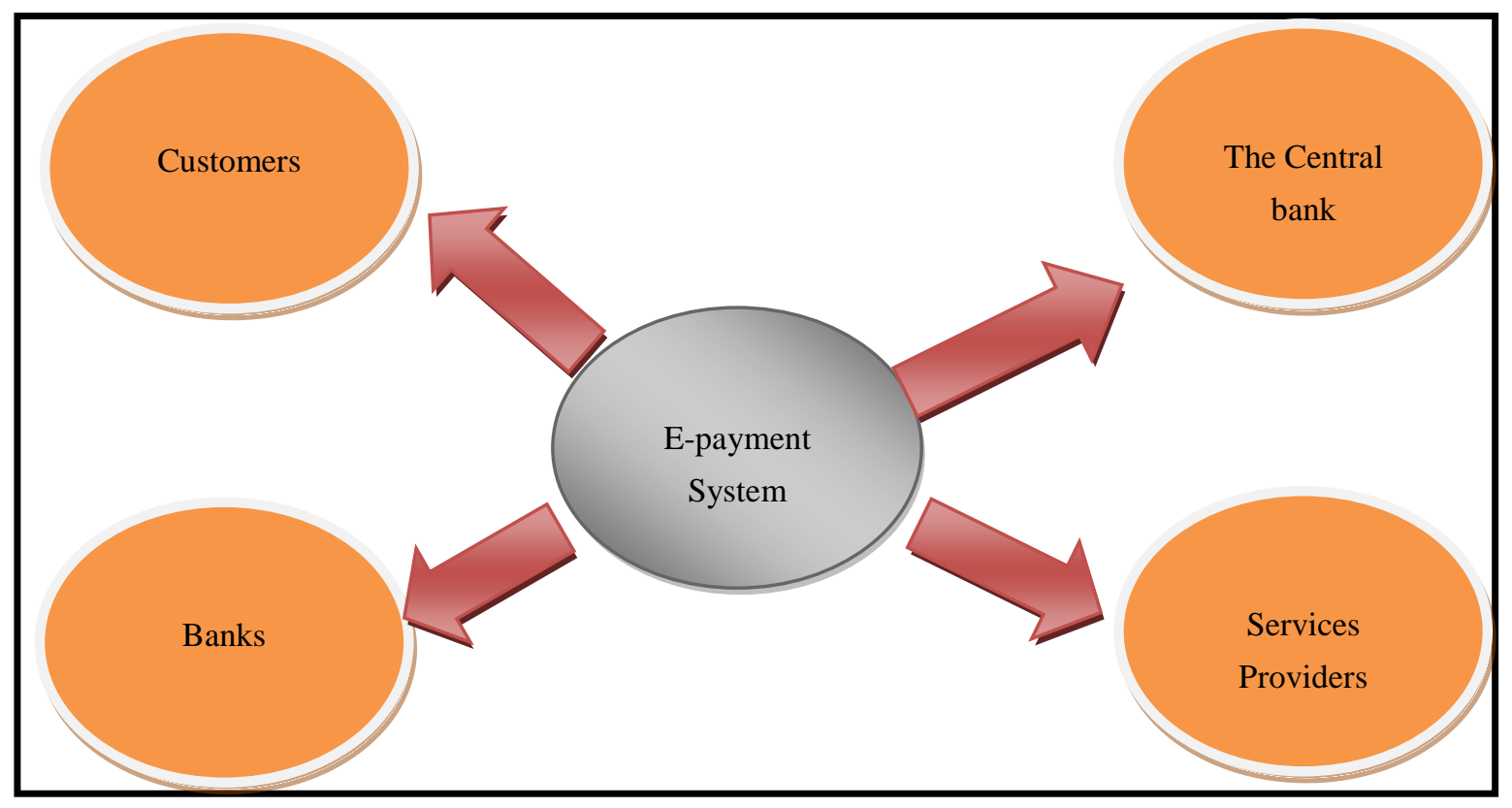

Figure 1. The e-payment system

The e-payments to subscribe in the display and collecting bills electronically. This allows customers to collect their financial claims quickly and effectively that saves time, money and effort. Table 2 shows the basic elements. 
Table 2. Element and components of e-payment

\begin{tabular}{|c|c|c|}
\hline & Components & Definition \\
\hline 1 & $\begin{array}{l}\text { Central Bank of } \\
\text { Jordan }\end{array}$ & President of the National Council of payments . \\
\hline 2 & Subscriber & abscriber of the service from billing source and any other authorities defined by the Central Bank. \\
\hline 3 & System & $\begin{array}{l}\text { Display and collecting bills electronically according to the terms and lows provided in this document and any } \\
\text { other regulation issued by the Central Bank in this regard. }\end{array}$ \\
\hline 4 & System Operator & $\begin{array}{l}\text { Commissioned authority by the Central Bank to operate and run the system (your payment company) for } \\
\text { e-payment or any other authority that replace them. }\end{array}$ \\
\hline 5 & Service & The service of displaying and collecting bills electronically, presented by the system . \\
\hline 6 & $\begin{array}{l}\text { Authority by which } \\
\text { payment done }\end{array}$ & $\begin{array}{l}\text { Any bank or licensed authority to receive financial payments in the kingdom that is connected with the } \\
\text { system, by which the consumers pay the subscribers entitlements through the different channels ( ATM , cell } \\
\text { phone, Banking phone< bank branch, selling points . }\end{array}$ \\
\hline 7 & customer & $\begin{array}{l}\text { Clients of subscriptions /or who deals with him / those who pay entitlements through authorities by which } \\
\text { payments is performed "repayment of the amount of money due in favor of the subscriber. }\end{array}$ \\
\hline 8 & Bills & $\begin{array}{l}\text { Bills / claims issued by "Subscriber" that the customer will repay through payment authorities in favor of the } \\
\text { subscriber. }\end{array}$ \\
\hline 9 & $\begin{array}{l}\text { A joint banking } \\
\text { account }\end{array}$ & $\begin{array}{l}\text { Joint baking account to register monetary amounts, for the "Bills" paid by "Customers". It details are shown } \\
\text { in the subscription contract. }\end{array}$ \\
\hline 10 & Commission & $\begin{array}{l}\text { The financial lump sum or the percentage of the bills value and / or the claim issued by the subscriber that } \\
\text { will be paid for collecting / paying the bill and / or claim or providing any other services through he system. }\end{array}$ \\
\hline 11 & Settlement & $\begin{array}{l}\text { The process of calculating the the net rights and obligations resulting from movements that have been cleared } \\
\text { by the system (RTGS-JO) or any clearing and settlement system credited by the central bank of Jordan to / on } \\
\text { the concerned banks accounts. }\end{array}$ \\
\hline 12 & $\begin{array}{l}\text { Means of personal } \\
\text { identifications }\end{array}$ & $\begin{array}{l}\text { Tools, information data that empower the subscriber to use the system. It is characterized with secrecy. It } \\
\text { includes name of subscribers, passwords, electronic signature, electronic documentation or any other personal } \\
\text { identification means. }\end{array}$ \\
\hline
\end{tabular}

The statistics presented in Table 3 and Figure 2 show that the numbers of payment services users increasing day after day. The number of movements performed through e-fawateercom during September is 52,669 payment movements with a total of $(4,941,407 \mathrm{JD})$. It was noticed that the payment movement done by the E-Fawateercom system increased in September about 1.650 with a total value of $(263,166$ JD) that is $3 \%$ increase in comparison with August 2015. The statistics showed that payment movements of E-Fawateercom increased in September with 44,011 movements with a total value (4,880,762 JD) with 508\% increase compared with the beginning of January 2015. The number of movements performed through the e-payment system (E-fawateercom) increased during September 2015 as 51,163 movement with a total value of $(4,880,762)$ in comparison with September 2014. Finally, the number of payments performed through e-Fawateercom since its launching till September are 284,420 payment movement with a total value (19,338.394 JD).

Table 3. A number and value of payment movements paid through E-fawateercom till September 2015

\begin{tabular}{|c|c|c|c|c|}
\hline \multirow{3}{*}{ Month } & \multicolumn{4}{|c|}{ the total Number of bills paid by the system } \\
\hline & \multicolumn{2}{|c|}{ Number } & \multicolumn{2}{|c|}{ Value in JD } \\
\hline & 2014 & 2015 & 2014 & 2015 \\
\hline January & 0 & 8658 & 0 & 382073 \\
\hline February & 0 & 11036 & 0 & 550596 \\
\hline March & 0 & 17308 & 0 & 783904 \\
\hline April & 0 & 20693 & 0 & 1092156 \\
\hline May & 71 & 31355 & 1821 & 1670878 \\
\hline June & 337 & 34658 & 10550 & 1950021 \\
\hline July & 767 & 40448 & 24610 & 2689749 \\
\hline August & 1097 & 51019 & 32992 & 4678242 \\
\hline September & 1506 & 52669 & 60645 & 4941407 \\
\hline October & 2167 & - & 75607 & - \\
\hline November & 3643 & - & 113950 & - \\
\hline
\end{tabular}




\begin{tabular}{lllll}
\hline December & 6988 & - & 279194 & - \\
Total & 16576 & 267844 & 599369 & 18739026 \\
\hline
\end{tabular}

Source: (http://www.cbj.gov.jo/upoloads, 2015 central bank of Jordan).

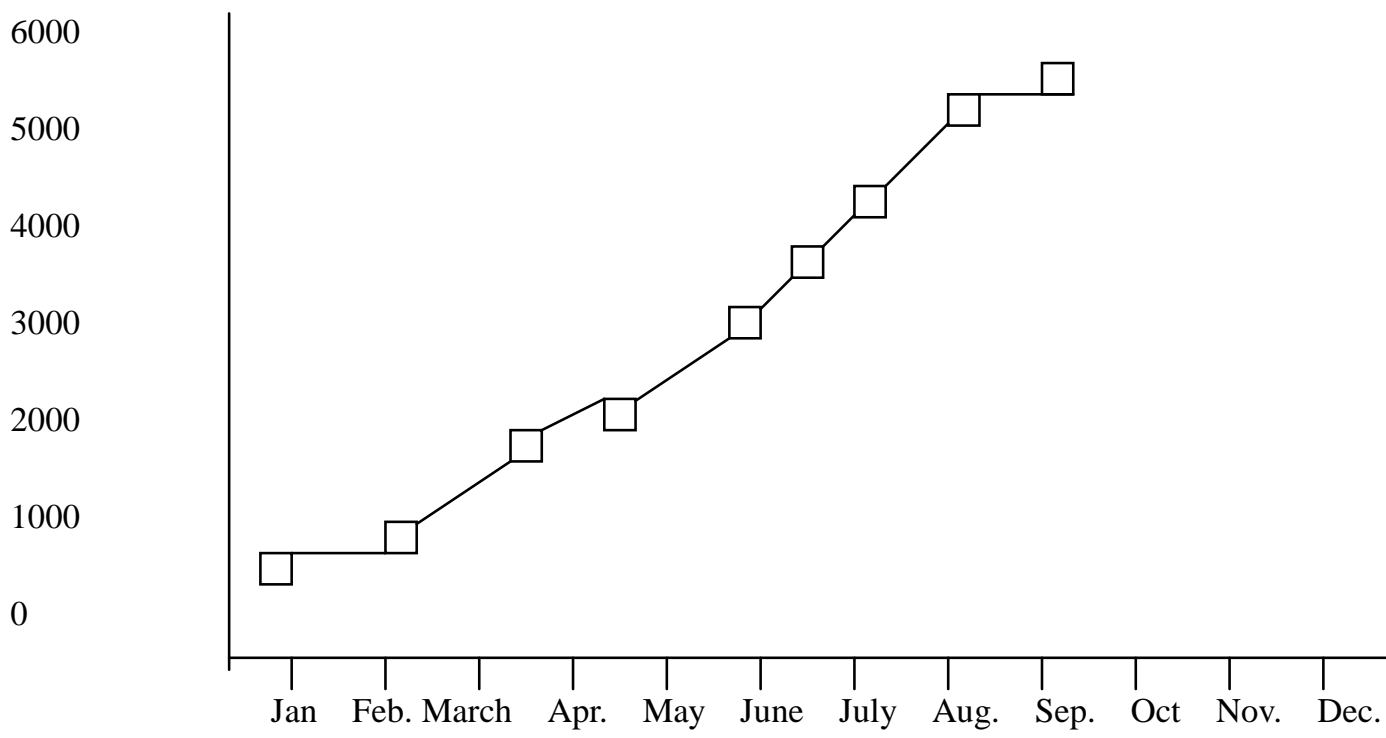

Figure 2. Number and value of movements paid through e-fawateercom till September payment movements performed through the system 2015 number of movements

Source: (http://www.cbj.gov.jo/uploads, Central Bank of Jordan. 2015).

The total number of services and their value in the Jordanian Dinar performed in all sectors till Sep.2015, the table shows the biggest number of e-payment performed in Jordan was for the communication sector (171933) movements with the biggest financial total value JD (2836692). In contrast, the least number of services by other service was in one operation for JD8-as in Table 3. In Table 4, there are names of companies that really perform for e-payment system in Jordan by sector till Sep, 2015. There are only 29 companies applying this system till now because the system is new and it is not well introduced to customers and companies.

Table 3a. The total number of services performed in all sectors and their value in Jordanian Dinar till Sep. 2015

\begin{tabular}{|c|c|c|c|c|c|c|c|c|}
\hline \multirow[t]{2}{*}{ Sector } & \multicolumn{2}{|c|}{ Communications } & \multicolumn{2}{|c|}{ Governmental Authorities } & \multicolumn{2}{|c|}{ Basic Service } & \multicolumn{2}{|l|}{ Charities } \\
\hline & Number & Value & Number & Value & Number & Value & Number & Value \\
\hline Total & 171933 & 2836692 & 9951 & 8203828 & 76179 & 7200662 & 830 & 69571 \\
\hline
\end{tabular}

Table 3b. The total number of services performed in all sectors and their value in Jordanian Dinar till Sep. 2015

\begin{tabular}{lllllllllll}
\hline Sector & \multicolumn{2}{l}{ Professional Associations } & \multicolumn{2}{l}{ E-Commerce } & \multicolumn{2}{l}{ Education } & \multicolumn{2}{l}{ Financial } & \multicolumn{2}{c}{ Other Services } \\
\hline & No. & Value & No. & Value & No. & Value & No. & Value & No. & Value \\
\hline Total & 2493 & 297622 & 6262 & 46407 & 66 & 74476 & 129 & 9760 & 1 & 8 \\
\hline
\end{tabular}

Source: (http://www.cbj.gov.jo/uploads2015, The central Bank of Jordan). 
Table 4. Names of companies that really apply the e-payment system in Jordan

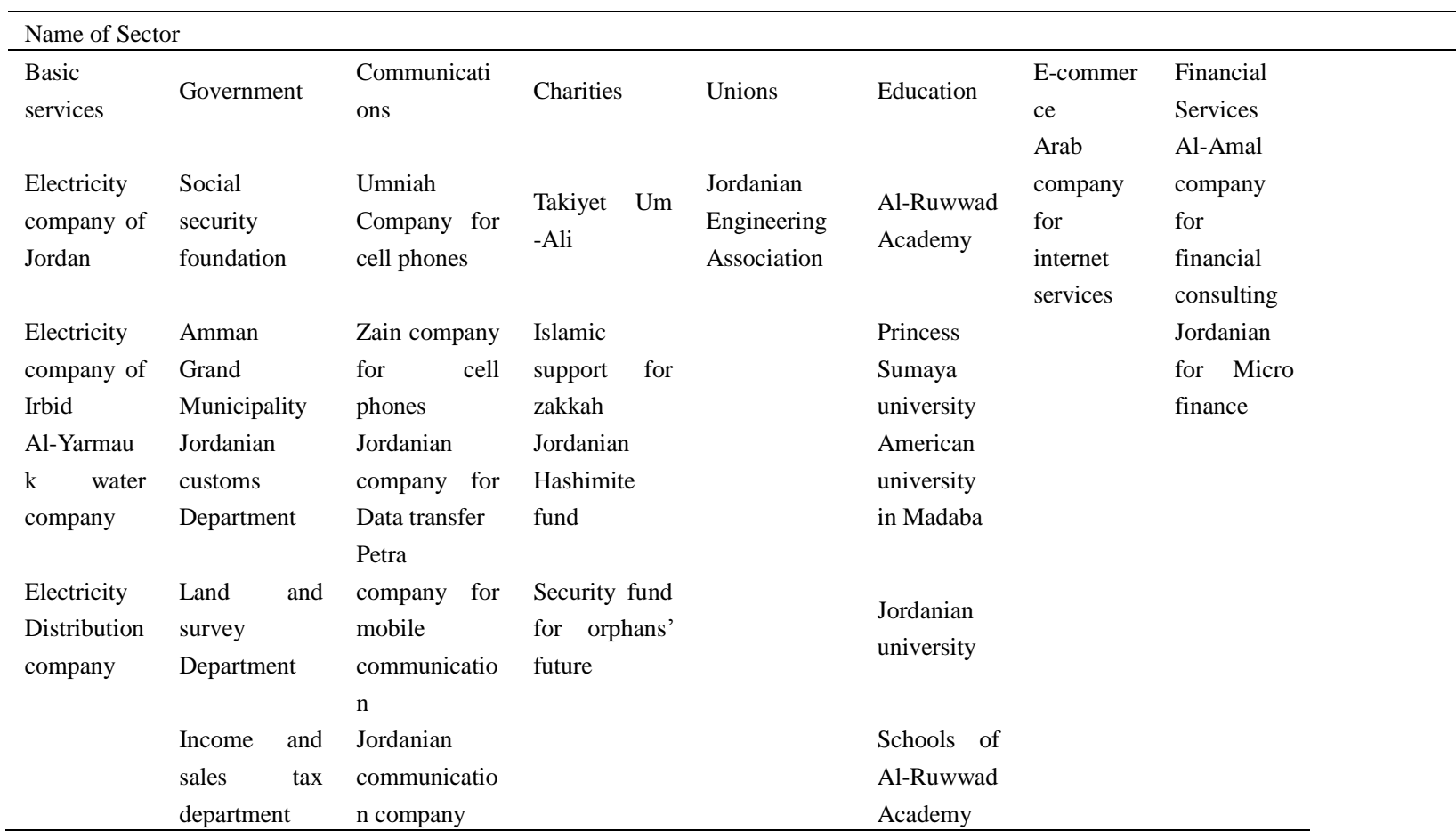

Source: (http://www.cbj.gov.jo/uploads, the central Bank of Jordan 2015).

\section{Previous Studies}

Through investigation and review of previous studies, the research observed that the applied researches were rare and theoretical studies dealt with the security concept and legislations. Some studies were found some studies (Al-Ma'aitah, 2013) and their effect on using e-payment in Jordan. The studies discussed the subject as pubic applications provided by the government, others as an application of e-commerce. These studies concentrated on identifying factors that affect on adopting the e-government services. Researchers will revise previous studies related to Jordan for the purposes of the study.

Study of (Al-rawabdeh, 2008) aimed at describing the percentage of the internet and e-commerce in Jordan. It indicated that there is a big gap between the internet performance in the developed countries like USA, Europe, Japan and Jordan is standing far away from these countries. The Jordanian market suffers from monopoly of providing internet services. This imposes high prices on customers which is the main reason of not developing the internet service and e-commerce in Jordan, in addition to some technological, economical, cultural and legal factors. The findings of the study showed that the different levels of using the internet for e-commerce purposes may be referred to the income and features of people, the percent of usage increases when the percentage of awareness and education increases. For example, lack of contents for the electronic websites in Arabic, being limited to English was one of the limitations that affect negatively the commercial practices through the internet. The social factor had a major and positive role in enhancing the concept of using the internet and e-commerce. The internet has the ability to make social changes in society like what the world witnesses these days from the social media networks effects in sending information quickly and cheaply. Finally the legal legislations play an important role in improving competency among users of e-commerce activities in Jordan. Jordan made serious steps in the direction of developing systems and legislations to fight hackings, to uncover them and send them to justice. The legal application is still in its initial stages which needs more follow-up and attention to encourage individuals to adopt different internet applications in general and the e-commerce in particular.

The study of (Al-Jaghoub, Al-yaseen, \& Al-Hourani, 2010) discussed the influencing factors on using the e-government services in Jordan by collecting data by individual interviews, groups of focus of Al-Ahliyya Amman University to know the level of using the e-government, and levels of awareness among the representing sample of Jordanian citizens. The results showed that the sample subjects' readiness to benefit from the e-government services in payments, issuing formal documents because of lack of trust in these websites and the prevailing culture in the society in Jordan that internet is for fun and not for financial affairs. Finally, the study 
recommended that Jordanian government should adopt a comprehensive strategy that expands the frame of dealing in providing e-government services to perform awareness campaigns that enrich citizens with knowledge and information about services. The government must provide guarantees of legal protection for the websites that provide e-services to make customers feel trust and safety.

The study of (Alsmadi, 2011) discussed the condition of using the internet in Jordan and Middle East countries. The neighboring countries are using internet services more that Jordan although Jordan id classified as one of the first countries to be ready for using internet services. This study concluded that there are some factors that limit or reduce using the e-government services in Jordan. These factors are divided into cultural factors and factors of trust when using the internet. Many electronic websites that provide governmental services were found without digital certificates or digital coding to protect personal information. The Ministry of Information Technology and Communications established a special department to protect the personal information of citizens. Jordanian customers don't trust in e-government service program and they don't have enough information that makes them real users for the program of e-government services. In contrast, the results of the study indicated that the internet network's infrastructure is available, supportive and wide spread to provide internet services in all areas quickly and cheaply. The government should have special laws legislations and systems for e-commerce transactions to protect users form hacking, fraud and problems. This may enhance the trust and security factor among users in Jordan.

The study of (Al-ma'aitah, 2013) indicated that some factors are behind not using the application of e-services as e-payment in Jordan. Despite the fact that this service is characterized with suitability and saving time for consumers. The most important factors that affect consumers for not using e-services are threats on privacy and security for consumers' information. Till the end of 2001, there were no laws and legislations to protect e-commerce transactions. The Jordanian consumers use the electronic means as ATMs and credit cards to purchase their needs an a limited basis comparison with consumers in modern countries like USA, France and Britain. They prefer the traditional methods to do these activities as they feel that current laws are unable to identify all sorts of dangers that they are subject to when using the electronic applications. The banks in Jordan are in danger of hacking on the customer's accounts to steel their balance and transfer them to other accounts.

To identify the reality of e-government services testing the challenges and barriers in Jordan, Shannak (2013) made interviews and focus groups to get necessary data to identify the factors that inhibit e-government services. This study divided the factors influencing the application of e-government in Jordan in to four factors: political, social, technological and organizational. Decision makers are more enthusiastic to the application of e-government, but because of providing financial sources and monetary support, they are reluctant. The social factors represented in the digital gap played a major role as an obstacle in front of the e-government applications. Most developing countries and Jordan suffer greatly from this gap. The latest statistics indicated that users of internet services are increasing in Jordan, but it is less than required. Technologically; the application of e-government program needs more modernization concerning systems, soft wares, and necessary equipment to apply the program. The most important software is that belongs to security and protection of their secret personal information in fear of hacking. It is necessary for the government to adopt these soft wares for protection to build trust among customers. The privacy factor is one of the obstacles that face the process of applying e-government in Jordan. Organizationally, the government has to reconsider its processes by training workers which will result in success of applying the e-government in Jordan. So, the Jordanian government is in need of obtaining informational strategy, a budget, costs planning coverage for internet network and equipment to ensure the effective usage of the e-government programs.

This study of (Al-Shboul, Rababah, Ghnemat, Al-Saqqga, 2014) at identifying the adoption of e-government services in Jordan. The study pointed out that introductory programs prepared before by the government to in traduce the e-government increased awareness about the nature of these services and how to use them. The results of the interview indicated that ready infrastructure to receive e-government services is sufficient to support applications and usages of this kind of services. The respondents indicated that they don't have any personal obstacles to use pos and internet technology like language, costs or individual skills, but they encounter obstacles toward using the e-government services. The results indicated the degree of high harmony between e-government services and life the interviewees as they find them compatible with their culture. They use the e-government services four to five times daily. On the other hand, that e-government service reduces costs, time and effort and contributes in the acceleration of providing services. It also helped in improving their lives economically, increasing productivity and the quality of services. The results of interviews showed that there are many obstacles that face the application of e-government in Jordan. The most important obstacles are that they need large amounts of investments; the size of information is so big for those public officers, the need for 
cultural awareness, a clear work strategy and a legal legislative system to protect users from hacking in Jordan. As the application of this kind of services encounters some dangers like lack of access to full information to customers, effective protection systems for the service programs and inability to control similar service systems. Finally, the study concluded that some organization, technological, social and financial factors encounter the process of adopting e-government services in Jordan.

Saleh (2015) study showed that tools and communication means are widespread in Jordan; as well as, several service providers of internet services, the percentage of adopting e-commerce in Jordan is still decreased in comparison with other countries as a result of the slow growth of e-commerce. This requires reorganizing means of accessing internet networks especially when the working organizations on applying e-commerce to protect themselves against the electronic dangers like piracy. This study used the model of Technology Acceptance Theory to identify the two effects of simplicity and welfare, in addition to the cultural factors on the attitudes of beneficiaries (Shoppers in Trading Malls) to use the application of e-commerce in Jordan. The results of this study indicated that simplicity affects positively on benefits related that in turn affects positively on the intentions of shoppers to use e-commerce in future. The applications of the e-commerce suffer from difficulties like low levels of trust among customers. The companies of private sector in Jordan may resort sometimes to using other communication means like phone calls, e-mails or face-to face that contribute in decreasing levels of experience by using e-commerce completely. Finally, the study indicated the necessity for those who put the legal frame will protect users and promote this system and its protection means to encourage customers to practice e-commerce activities in Jordan.

By using the technology acceptance model, the two researchers (Al-Jamal \& Abu-Shanab, 2015) performed a study about adopting the e-government services in Jordan through testing two main factors in this model: simplicity and welfare in addition to the effect of age factor on the process of adopting the e-government services. An extension appeared of this model, it is a negative effect on the intention of customers in adopting this type of services. Based on the results of this study, the two researchers recommended that the success of the e-government program is not the responsibility of society only, but it is a common responsibility between society and responsible authorities (The Ministry of Information Technology and communications) for applying this program. The government should do several procedures that improve the level of communication, knowledge and necessary skills among users through the introductory programs, seminars and workshops that highlight the importance and e-government service role in our daily life.

\section{Study Framework Hypotheses}

Based on the discussion of literature and previous studies mentioned in the previous section, the researchers noticed that most studies discussed the real situation of the e-government program in Jordan, the scenarios of e-commerce and levels of its application in Jordan. Most studies aimed at achieving and identifying the most important influencing factors on using and adopting the e-government in Jordan and the influential relationships between these factors and accepting this technology by the customers in Jordan. To build this special model for the study, the researchers tried to identify these factors through the problem of the study by revising the most important factors that affected the reality of applying the e-government and e-commerce in Jordan that ignored research in the most important directed services by the e-government, that is e-payment services (e-Fawateercom), They found that these factors are several and varied and affect the customer's attitudes and intention in adopting e-payment services through highlighting the factors that affect positively or negatively on adopting and applying such services in Jordan. The model of this study was designed to measure the effect of five factors are relative advantages, simplicity, security, awareness and individual skills related to intention of commercial bank's customers toward e-payment services in Karak governorate.

\subsection{Hypotheses of the Study}

Based on above, there are five main hypotheses that measure the effect of, simplicity, safety, social network, Awareness and personal skill on the attitudes of bank customers in adopting e-payment in the Karak governorate. These hypotheses were formulated as follows:

1) The first main hypothesis: There is a positive and significance effect of relative advantages on the customers intention toward e-payment services in Karak.

2) The second main hypothesis: There is a positive and significance effect of simplicity on the customers intention toward e-payment services in Karak.

3) The Third main hypothesis: There is a positive and significance effect of security on the customers intention toward e-payment services in Karak. 
4) The fourth main hypothesis: There is a positive and significance effect of consciousness on the customers intention toward e-payment services in Karak.

5) The fifth main hypothesis: There is a positive and significance effect of individual skills on the customers intention toward e-payment services in Karak.

\section{Methodology of the Study}

In this study, the descriptive analytical methodology was applied to describe the phenomenon of using e-services in general, trying to describe the condition of using and applying e-payment services in Jordan. The researchers tried to identify the effect of a group of factors that might have significant effect adopting this kind of services in the study environment to be expressed in a descriptive way in addition to the quantitative expression that will appear through the results of the study hypotheses under the influence of attitudinal, social and control factors on the customers intentions in adopting e-payment services in the Jordanian environment.

\subsection{The Study Population}

The population of the study included all customers of working commercial banks in Al-Karak governorate, about 180.000 people distributed on 11 commercial banks. This number was obtained un officially through direct questions for managers of banks in the concerned area as numbers of customers are private data and secret dealing. The two researchers estimated the number of customers by reference to the approximate figures they obtained from managers in the working banks in relation to the population of the governorate, which is up to 450.000 in habitants nearly (Dos, 2015).

\subsection{The Study Sample}

To choose a representing sample from the population of the study, (Krejcie \& Morgan, 1970) pointed out that if the study sample included (100.000) respondents, the size of questionnaires necessary for distribution shouldn't less than (384) to ensure a representing study sample. To ensure the retrieval of an adequate number of the study sample, and exclusion of those that might contain mistakes or not complete six hundred (600) questionnaires will be distributed on all customers of working commercial banks within the boundaries of Karak governorate. To ensure giving equal opportunities for all members of the study sample, the simple random sample was applied on the commercial bank's customers in Karak governorate. And that by relying on a group of bank employees who expressed their full cooperation for the success of the process of collecting specific data. The process of distributing questionnaires and retrieving them continued for the period between (26/7/2015-10/8/2015) the actual rate of six weeks.

\subsection{Data Collection Approach}

This study aimed at obtaining adequate and necessary data to achieve specific goals for two main types of data.

\subsubsection{Secondary Data}

In order to get all related data, they referred to many literary sources in the field of information technology, communicationE-government and Central Banks' brochures. In addition, the most recent studies, scientific arbitrary essays that are published in editorials and database and internet network as a major source for getting the latest data and research studies related to the subject of the study.

\subsubsection{Preliminary Study Data}

A questionnaire was built to test the hypotheses of the study and to about the preliminary data by which the statements of the dependent and independent variables of the study were measured. The statements of previous studies were used and modified to be suitable for the subject of the current study.

\subsubsection{Data Collection Tool}

This study depended on a questionnaire designed for the study to collect preliminary data. The questionnaire is formed from three main parts. The first part is about a coverage letter that includes a question to classify the respondents who uses the internet only to ensure obtaining uses of internet technology (Are you an internet user or not? If your answer is No, please stop now). It points out to the title of the study and statements to fill the questionnaire, the secrecy of dealing with data and communication information with the two researchers. The second part, it includes a group of questions related to respondent's demographic information and information related to using the available electronic means that help customers to adopt e-payment services by customers of commercial banks in Karak Governorate. This part included investigating about (social type, age, qualification, monthly income, the period of using the internet and means of using the internet). The third part of the questionnaire includes 20 statements to measure independent variables in this study. These independent variables 
are attitudinal factors represented in (relative advantages in five statements, simplicity in four statements, security in three statements and consciousness in three statements, the individual skill in four statements) and four statements for the dependent reliable (customers intention toward e-payment services). To measure statements of this questionnaire, 5-likert scale was credited as in Table (5). To ensure the validity of the tool, the questionnaire was presented to five arbitrators from Jordanian universities where their observations and recommendations were taken into consideration and all of them were entered on the questionnaire items. After that the questionnaire in its final version was tested on an experimental sample that included 30 respondents to ensure the ability of the sample to respond to its final items where this sample was not used in the final analysis results.

Table 5.5 likert-scale to measure the degree of responses

\begin{tabular}{cccccc}
\hline Response & Strongly Agree & Agree & Neutral & Disagree & Strongly Disagree \\
\hline Degree & 5 & 4 & 3 & 2 & 1 \\
\hline
\end{tabular}

\subsection{Statistical Analysis Style}

The statistical package software for social sciences (SPSS) V.18 was used to do a variety of statistical tests that contribute in describing the data of study sample, the percentage of responses, identifying wrong and abnormal answers, the normal distribution, validity and compound validity, and correlation between variables. The Linear Equation Model (LEM) AMOS software V.8.

\section{Results of the Study}

\subsection{Ratio of Responses}

Six hundred questionnaires were distributed to obtain preliminary data for this study from customers of commercial banks in Karak. After collecting responses from the sample of the study, the number of retrieved questionnaires was 543 responses only, \%90.5 as ratio of responses where this is an accepted to enter them for statistical analysis. After that it was initiated by entering data to Statistical Package Software (SPSS). It is shown that there are seven (7) incomplete answers, some them contained major mistakes that can't be ignored. They were excluded from the final analysis. So the ratio suitable for analysis was $\% 89.3$ as 536 responses.

\subsection{Description of the Study Sample Features}

Frequency tests were conducted to describe the characteristics of the study sample. The tests included six main questions (the social type, age, qualification, Monthly income, duration of using the internet and the tool of using the internet). This is a presentation for these results as in Table 6.

Table 6. Distribution of the population of the study sample according to the sample's features

\begin{tabular}{llll}
\hline Variable & Variable Categories & Number & Ratio\% \\
\hline \multirow{4}{*}{ Social Type } & Males & 415 & 77.5 \\
& Females & 121 & 22.5 \\
& Total & 536 & $\% 100$ \\
\hline \multirow{4}{*}{ Age } & Less than 30 years & 212 & 39.5 \\
& 30-40 years & 187 & 34.8 \\
& $41-50$ years & 88 & 16.4 \\
& 50 and more & 49 & 9.3 \\
& Total & 536 & $\% 100$ \\
\hline \multirow{4}{*}{ Qualification } & PhD & 37 & .07 \\
& MA & 91 & 17. \\
& BA & 303 & 57 \\
& Diploma & 44 & .08 \\
Income & Secondary\& less & 61 & 11. \\
& Total & 536 & $\% 100$ \\
\hline
\end{tabular}




\begin{tabular}{llll}
\hline & $500-250$ & 71 & .13 \\
& Less than 250 & 22 & .04 \\
& Total & 536 & $\% 100$ \\
\hline \multirow{5}{*}{ Duration of using the internet } & 4 years \& less & 62 & 11.5 \\
& 5-9 years & 298 & 55.6 \\
& More than 10 years & 176 & 32.9 \\
& Total & 536 & $\% 100$ \\
\hline \multirow{5}{*}{ Tool of using the internet } & Laptop & 187 & 35. \\
& Pc & 88 & 16.4 \\
& Cell phone & 261 & 48.6 \\
& Total & 536 & $\% 100$ \\
\hline
\end{tabular}

Table 6 showed the distribution of the subjects of the study depending on the variable of social type. The number of males is (415) by (77.5\%) where as females is (121) by (22.5\%). Table 6 showed the distribution of the subjects of the study depending on the variable of age, 212 subjects $(39.5 \%)$ of the study sample are less than (30) years and 187 by (34.8\%) their age (30-40) years, 88 of the respondents $(16.40 \%$, their ages between (30-41) and 49 respondents their ages are more than 50 years by $(9.3 \%)$.

The results showed the number of respondents who had a ph degree (37) by $(0.7 \%)$. There were (91) respondents who had MA degree $\mathrm{b}(0.17 \%)$. The highest percentage was for those who had BA degree. The number of responses for this category was 303 responses by $(57 \%)$ and Diploma holders about 44 respondents by $(0.08 \%)$. The respondents who had secondary or less, their ratio were 61 respondents by $(0.11 \%)$. The table showed that 63 respondents' income was JD 1000 by $12 \%$. The income of 246 respondents was $750-1000$ by $46 \%$. Whereas the respondents whose income between $749-501$ were 134 respondents by $25 \%$. The highest percentage was for 71 respondents. Their income was 500-250 by $13 \%$. The least monthly income was for 22 respondents. Their income was less than 250 by $0.04 \%$ of the study sample.

Table 6 showed that the highest percentage came from the category of users of internet technology from (5-9) years by (55.6\%). The internet users for more than 10 years came in the second place with 176 respondents by (32.9\%), followed by third category with 62 users from the total sample by $(11.5 \%)$, it was the least category of internet users of services. Most of the study sample subjects use cell phones to reach internet network (261) respondents with (48.6\%). The percentage of users of internet through laptop 35\%, they were 187 respondents. Finally, the number of internet users through PCs was 88 respondents with a percentage (16.4\%).

\subsection{Testing the Reliability and Composite Reliability}

To test the reliability of the study variables, Cronbach Alpha was used by using SPSS no.18 to test the internal stability. The studies showed that it should more than $60 \%$ percent age so that the result will be statistically accepted (Numnally, 1970; Bagozzi \& Yi, 1989).

Table 7. The value of reliability and composite reliability for the study variables

\begin{tabular}{lll}
\hline Variables of the study & C Alpha & COM reliability \\
\hline Relative advantages & 0.791 & 0.862 \\
Simplicity & 0.831 & 0.892 \\
Security & 0.843 & 0.902 \\
consciousness & 0.901 & 0.951 \\
Individual Skill & 0.911 & 0.914 \\
Intention toward e-payment service & 0.792 & 0.942 \\
\hline
\end{tabular}

\subsection{Multi Collinearity Test}

The study results in Table 8 showed that the correlation values between the variable were all accepted statistically as they didn't exceed the upper limit of the statistical value (0.80\%) (Hair et al., 2010). The correlation values ranged between variables between 309 between the individual skill factor and the correlated related benefits as the least value, were as the multi collinearity value between individual skill and personal skill and perception, it was .685 as the highest value. So, all the values are statistically accepted. They expressed lack of the linear correlation problem between the variables statistically. 
Table 8. Results of analysis of correlation between variables

\begin{tabular}{lllllll}
\hline & $\begin{array}{c}\text { Relative } \\
\text { advantages }\end{array}$ & Simplicity & security & consciousness & $\begin{array}{c}\text { Individual } \\
\text { skills }\end{array}$ & Intention \\
\hline $\begin{array}{l}\text { Relative } \\
\text { advantages }\end{array}$ & 1 & & & & \\
Simplicity & .622 & 1 & & & \\
Security & .576 & 0.612 & 1 & & & \\
Awareness & 0.465 & 0.541 & 0.632 & 1 & 1 & \\
Individual skills & 0305 & 0.463 & 0.574 & 0.685 & 1 \\
intention & 0.487 & 0.523 & 0.389 & 0.581 & 0.567 & 1 \\
\hline
\end{tabular}

\subsection{Normality Test}

The results of Normality test showed that all values of variable normally distributed and complete free of the extreme values as in Table 9. Based on using Kolmogorov-Smirnov, where (Gujarati, 2010) indicated if the Sig. value is bigger than 0.05 , the value of variable follow the normal distribution and there are no extreme values to affect in the model within the sample.

Table 9. Normality test (The normal distribution test)

\begin{tabular}{lll}
\hline Study Variables & Statistics & Sig. \\
\hline Relative advantages & 1.734 & 0.111 \\
Simplicity & 1.562 & 0.132 \\
Security & 1.675 & 0.121 \\
consciousness & 1.242 & 0.103 \\
Individual Skill & 1.536 & 0.115 \\
Intention & 1.621 & 0.157 \\
\hline
\end{tabular}

\subsection{Testing the Study Hypothesis}

As we mentioned before, AMOS.V8 was used to test the study hypothesis to identify the direct of the independent factors represented in (Related benefits, Simplicity, Safety, Awareness and Individual Skill) on the dependent variable (attitudes of bank customers in adopting e-payment services in Karak Governorate). Table 10shows the estimated values of the independent factors on the dependent factor and the current ratio toward the relationship (current ratio, CR) and (P-Values).

Table 10. Results of study hypothesis

\begin{tabular}{cllllll}
\hline Study Hypothesis & $\begin{array}{l}\text { Independent } \\
\text { Variables }\end{array}$ & $\begin{array}{l}\text { Dependent } \\
\text { Variable }\end{array}$ & Estimate & C.R & P-value & $\begin{array}{l}\text { Hypothesis } \\
\text { contortion }\end{array}$ \\
\hline H1 & $\begin{array}{l}\text { Relative } \\
\text { advantages }\end{array}$ & Intention & .021 & 1.110 & .721 & Rejection \\
H2 & Simplicity & Intention & .211 & 3.547 & 1.31 & Acceptance \\
H3 & Security & Intention & .613 & 9.425 & $* * *$ & Acceptance \\
H4 & consciousness & Intention & .251 & 4.241 & .012 & Acceptance \\
H5 & Individual Skill & Intention & .498 & 6.473 & $* * *$ & Acceptance \\
\hline
\end{tabular}

Based on the previous table, the results showed the acceptance of four hypotheses, related to simplicity, safety, awareness and the individual skill on the intention of working commercial banks in Karak toward e-payment services. One hypothesis of the Relative advantages on the customer intention of working commercial banks toward e-payment services was rejected. The results indicated that Relative advantages affect positively, but with no statistical significance on the customers intention toward e-payment services $(\mathrm{C} . \mathrm{R}=1.110 ;=.721,021 .=\mathrm{B})$, so the first hypothesis was rejected. The finding indicated that the simplicity factor had appositive effect of statistical significance on the customers intention toward e-payment services (C.R=3.547; P=0.31, .211=B). So the second hypothesis was accepted. The result was $(* * *=C . R=9.425 ; \mathrm{P}, .613=\mathrm{B})$. The consciousness factor had 
a customers in toward e-payment services ( $\mathrm{C} . \mathrm{R}=4.241 ; \mathrm{P}=.012, .251=\mathrm{B})$, so the fourth hypothesis was accepted in the study. Finally, it is indicated that individual skill had a positive effect of statistical significance on the customers intention toward e-payment services $(* * *=\mathrm{C} . \mathrm{R}=6.473, \mathrm{P}, .498=\mathrm{B})$, so the fifth hypothesis was accepted in the study.

\section{Discussion of the Results}

The results related to the description of the study sample indicated that most of the subjects of the study were males. This is due to the environment in Karak as it still lacks jobs for females to work in the field of education and other limited opportunities available in the army, banks and mining sector. This refers to the common culture in the Jordanian society that resulted in an increase in the number of males compared to the number of females. The result of description showed that most respondents are from the early youth category who is less than 30 years. This emphasizes that the category that uses technology mostly is from young people who usually like using it in different fields like the internet. This category is considered the most accepting for the technological means in daily usage. The results showed clearly that the study sample include subject who had scientific certificates and qualifications ranged from BA, higher studies like MA and PHD. The study sample subjects utilize the most important educational facility inside Karak Governorate to learn there or getting a job, on the grounds that scientific qualifications will help them to get jobs and advance in their career. According to the income of banks customers in Karak Governorate, the findings indicated that the majority of medium-income ranged from JD (750-1000). This is due to the nature of jobs available for study society like jobs in public sector and security organizations on which the population of Karak Government depend on greatly. These jobs are of medium-income in addition to few opportunities in private sector like companies, schools and banks.

The results of the study sample description that most respondents had 5 years and more experience in using the internet. This result emphasized that youth that was high previously are the most users of technology of internet. They used internet widely to practice their career and life activities and others. This is clear evidence on the internet spread and easy access to it for a reasonable period of time that might reflect their experience in utilizing it in a good way.

In terms of access to the internet networks, the results indicated that most of subjects of the sample of those who use smart phones. This means is used on a large scale as the internet pages enable them to surf and access all sites easily and quickly with no complications because of harmony in the nature of obtaining cell phones because of their individual specifications about using laptop or PC.

Concerning testing the study hypotheses, the results of the study indicates: Firstly, the rejection of the first hypothesis that stated that there was appositive effect of statistical significance for the related benefits on the banks customers intention in Karak Governorate toward e-payment services. This result indicated that relative advantages don't affect morally on the attitudes of customers to adopt this type of technology. This point out that the study sample doesn't realize completely the importance of benefits, interests and characteristics that will get. They will be reflected on them if they are real users of this technology. Not having the values and results really makes them unable to judge on the extent of making use of these services. So the providing authorities responsible for applying and performing e-payment services to provide experimental opportunities for the customers to apply this system to reflect the benefits and characteristics on their positive attitudes.

Secondly, the acceptance of the second hypothesis is that states the existence of positive effect of statistical significance for simplicity on the banks customers intention of banks in Karak Governorate toward e-payment services, the result of accepting this hypothesis states that customers always prefer these systems providing e-service they can deal with them easily with difficulties that may annoy or alienate them while using them. They always look for easy applications to surf them easily and understand content, an easy language of the system, the steps are clear and easy access to the wanted services. The result of the hypothesis explains that ease of use factor is one of the factors that users pay attention to them because of their importance e-payment systems should pay more attention to this dimension greatly, and they should simplify the steps to access them to encourage customers to adopt this type of e-services.

Thirdly, acceptance of the third hypothesis that stated the existence of a positive effect with statistical significance for safety factor on the banks customers intention of banks in Karak Governorate toward E-payment services. The factor of safety occupied the first place in importance between factors that influence by necessity of providing the safety element for the internet users when using e-services in general, especially when these services are related to the financial issues. Customers tend greatly to adopt available services from websites that impose protection for dealers to support them, enhance trust and trying to convince of low levels of risk in getting their services which is the most basic factors that affect negatively using e-government services by the 
citizen, the customer is afraid of displaying, exposing his personal information, stealing his account or performing fraud operations on personal data to use them illegally. The government must plan clear strategies to build high degrees of trust between citizens and government especially in the field of e-government and e-payment services, as well as creating legal and legislative frame works that aim at protecting commercial transactions electronically, impose, sanctions on those who manipulate in the fields and applications of e-commerce. There must be a system of questioning and especially for e-commerce transactions that aim at increasing the citizen's interaction, reducing his fears under an effective, transparent system for communication and uncovering information between the government and the citizen.

Fourthly, accepting the fourth hypothesis: That states the existence of a positive effect of statistical significance for the factor of consciousness on the banks customers intention in Karak Governorate toward e-payment services. The study sample indicated the importance of this factor on the attitudes of customers. This effect is reflected proportionally between awareness and use average. The more increase in awareness degrees among individuals about a specific service, the more percentage of adopting and using this service. This result explains that customers always want to use the services they know more information about their features and advantages, how to get this service and the effect of using this type of services. The government must plan programs, workshops to increase awareness among citizens and customers about available e-payment services to make use of it and to save time and effort. It is necessary for the concerned authorities on the system among all categories of society in this technology, making them more perceptive and aware of improvements that come up on the services, by issuing introductory booklets with photos and editorial brochures in addition to launching awareness campaigns in all parts of Jordan supported by mass media.

Fifthly, Acceptance of the fifth hypothesis: That stated the existence of a positive effect of statistical significance for the individual skill factor on the banks customers intention of banks in Karak Governorate toward e-payment services. This result emphasizes the individual ability on using technological means that allow the customer to access different technological applications. The major factors that affect the customers to adopt e-payment services. It is noted that most customers who do not want to use technological tools such as ATM are elderly people or uneducated ones. This reflects their inability to use these technologies because of the lack of scientific and technical skills that help them to adopt services. This result emphasized that the subjects of the sample have basic requirements to use e-payment services, represented by their ability to use the PC or using a cell phone that gives them the opportunity to surf the internet network, searching for information, obtaining the services in addition to the possibility of using systems providing these services and adopting e-payment systems if they have this chance in future.

\section{Scientific contribution}

This study is considered one of the rare studies that discussed the subject of adopting e-payment services in Jordan, especially the majority of previous studies discussed adopting e-government services in general or investigating the factors that influence customers in e-purchasing issues and e-commerce. We found only one study that discussed the subject of using e-payment services (Al-Ma'aitah, 2013). This study is limited to investigating the risk factor. It was before launching e-payment services in Jordan that started its work in 2014. This study is built on two scientific contributions. The first one is academic; that is made by building a theoretical model which discusses a group of building a theoretical model which discusses a group of factors indicated by the results of the study as the most important that affect the customers to adopt e-payment services in Jordan. This research tried to identify the degree of importance for each factor, and to discuss reasons behind its importance. This study performed an applied contribution in some of the Jordanian environments (Al-Karak Governorate) which doesn't show interest in research subjects. These researches are done in cities and main centers like Amman, Irbid, and Zarqa ignoring the environment of other governorates, in addition to the main objective of this research; to come out with applied results and handing them over to decision makers and developers of e-payment system to be used by service institutions who never used e-payment systems by identifying this system. This contributes in encouraging systems and exerting future efforts to apply it to attract customers to its services.

\section{Limitations of the Study}

1) Previous studies that discussed the subject of e-payment service (e-fawateercom) in Jordan were rare. The two researchers were obliged to use related studies concerning e-government services and studies of e-commerce.

2) The process of obtaining sample data: it was very difficult to obtain the true numbers for the study sample like customers of commercial banks in Karak Governorate. The two researchers had to deal with approximate figures with the help of some employees in these banks. These data are secret information for the use of the bank itself. 
3) This study applied its model in Karak Governorate. It is difficult to over generalize the results of the study on the rest of the governorates in Jordan. Because of different factors: economical, cultural and social between Karak and Amman.

4) This study is limited to identify the influence of some factors represented in the related benefits, simplicity, awareness and individual skills on the attitudes customers adopt e-payment services. The study ignored many factors like social, economical and legal factors and others. We hope there will be more future researches by discussing them in their studies.

\section{Conclusion}

This study aimed at identifying the importance of a group of factors that represented in (related benefits, simplicity, safety, awareness and individual skill) on the attitudes of customers of commercial banks toward adopting e-payment services (e-fawateercom) in Karak Governorate. Based on accessing preliminary data by designing a questionnaire .It was randomly distributed on the customers of banks in Karak Governorate in a way that takes into consideration the ratio of customers' numbers in every bank. About 600 questionnaires were distributed on the sample. Only 543 responses were retrieved with \% 90.5 percentages. They were accredited and analyzed through (SPSS no.18) by conducting some statistical test like test of sample description, stability and compound stability, normal distribution, correlation between variables, in addition to using (AMOS) software no. 6 in order to test hypotheses to identify the ratio of the effect of independent factors on the dependent factor.

The results of this study indicated the acceptance of four hypotheses from five. The first hypothesis was rejected. It indicated the nonexistence of a positive effect of statistical significance for the relative advantages factor on the attitudes of customers of working commercial banks in Karak Governorate. The security factor occupied the most important factor for the customers of banks followed by the individual skill factor, then awareness then simplicity sequentially according to the importance of effect on banks customers intention toward e-payment services in Karak Governorate. The study included the discussion of results that concluded some recommendation presented to the decision makers concerning results that achieved a group of points mentioned by this study with its scientific and applied contribution, and mention some limitations that face this study.

\section{References}

Abu-Shanab, E. (2012). Digital Government Adoption in Jordan: An Environmental Model. Int. Arab J. e-Technol., 2(3), 129-135.

Al Nagi, E., \& Hamdan, M. (2009). Computerization and e-Government implementation in Jordan: Challenges, obstacles and successes. Government Information Quarterly, 26(4), 577-583.

Al-Jaghoub, S., Al-Yaseen, H., \& Al-Hourani, M. (2010). Evaluation of awareness and acceptability of using e-government services in developing countries: The case of Jordan. The Electronic Journal Information Systems Evaluation, 13(1), 1-8.

Al-Jamal, N. Q., \& Abu-Shanab, E. A. (2015). E-Government Adoption in Jordan: The Influence of Age. The 7th International Conference on Information TechnologyICIT 2015, 345-350.

Alrawabdeh, W. (2014). Environmental Factors Affecting Mobile Commerce Adoption-An Exploratory Study on the Telecommunication Firms in Jordan. International Journal of Business and Social Science, 5(8), 151-164.

Al-Shboul, M., Rababah, O., Ghnemat, R., \& Al-Saqqa, S. (2014). Challenges and Factors Affecting the Implementation of E-Government in Jordan. Journal of Software Engineering and Applications, 7(13), 1111.

Al-Sobhi, F., Weerakkody, V., \& Al-Busaidy, M. (2010). The Roles of Intermediaries in the Diffusion and Adoption of E-Government Services. Proceedings of the European and Mediterranean Conference on Information Systems, pp. 1-17.

Atwah, A. M. (2013). Security Concerns in E-payment and the Law in Jordan. International Journal of Advanced Computer Science and Applications, 4(7), 179-183.

Bagozzi, R. P., Baumgartner, J., \& Yi, Y. (1989). An investigation into the role of intentions as mediators of the attitude-behavior relationship. Journal of Economic Psychology, 10(1), 35-62.

Elsheikh, Y., Cullen, A., \& Hobbs, D. (2007). E-government in Jordan: Challenges and Opportunities. Transforming Government People Process \& Policy, 2(2), 83-103. 
Gujarati, D. N. (2003). Basic Econometrics (4th ed.). New York: McGraw-Hill.

Hair, J. F. (2010). Multivariate data analysis (7th ed.). New York, NY: Prentice Hall.

Heba, M., Tamara, M., \& Amer, A. (2009). E-Government in Jordan.Working paper, European Journal of Scientific Research, 35(2), 188-197.

Krejcie, R. V., \& Morgan, D. W. (1970). Determining sample size for research activities. EducPsychol Meas.

Nunnally, J. C. (1970). Introduction to psychological measurement.

Saleh, Z. (2015). Factors Affecting the Growth of E-Commerce in Jordan.International Journal in Management and Social Science, 3(5), 104-117.

Shannak, R., \& Aldhmour, F. (2009). Grounded theory as a methodology for theory generation in information systems research. European Journal of Economics, Finance and Administrative Sciences, 15, 32-50.

Shannak, R. O. (2013). The Difficulties and Possibilities of E-Government: The Case of Jordan. Journal of Management Research, 5(2), 189-204.

Ministry of information communication technology. (2015). Retrieved august 5, 2015 from http://www.moict.gov.jo/HOme.aspx

Jordan population. (2015). Retrieved august 5, 2015 from web.dos.gov.jo

Information and communications sector. (2015). Retrieved august 5, 2015 from http://www.jordan.gov.jo/wps/portal

Central bank of Jordan. (2015). Retrieved august 5, 2015 from http://www.cbj.gov.jo/arabic/

Internet users numbers. (2015). Retrieved august 5, 2015 from http://www.internetworldstats.com/

\section{Copyrights}

Copyright for this article is retained by the author(s), with first publication rights granted to the journal.

This is an open-access article distributed under the terms and conditions of the Creative Commons Attribution license (http://creativecommons.org/licenses/by/3.0/). 